\title{
Verstaanbare prediking is eenvoudige prediking: 'n Prakties-teologiese besinning oor die styl van prediking
}

\author{
Author: \\ Ferdinand P. Kruger ${ }^{1}$ \\ Affiliation: \\ ${ }^{1}$ School for Ecclesiology, \\ Potchefstroom Campus, \\ North-West University, \\ South Africa \\ Correspondence to: \\ Ferdinand Kruger \\ Email: \\ ferdikruger4@gmail.com \\ Postal address: \\ PO Box 75973, Lynnwoodrif \\ 0040, South Africa \\ Dates: \\ Received: 19 Mar. 2011 \\ Accepted: 04 July 2011 \\ Published: 27 Nov. 2012 \\ How to cite this article: \\ Kruger, F.P., 2012, \\ 'Verstaanbare prediking is \\ eenvoudige prediking. 'n \\ Prakties-teologiese besinning \\ oor die styl van prediking', \\ In die Skriflig/In Luce Verbi \\ 46(2), 11 pages. http://dx.doi. \\ org/10.4102/ids.v46i2.62
}

C 2012. The Authors

Licensee: AOSIS

OpenJournals. This work

is licensed under the

Creative Commons

Attribution License.
Prediking is intensioneel en wil verandering bewerk. Onder die prediking vind interaksie en kommunikasie tussen prediker en hoorder plaas. Die oomblik wanneer die prediker skryf of praat, maak hy of sy van styl gebruik. Styl is vir die prediker soos die kleur wat 'n kunstenaar gebruik. Die navorsingshipotese in die artikel is dat gebrekkige styl daartoe bydra dat God nie reg gehoor word in die prediking nie. In hierdie artikel word van 'n driedeling gebruik gemaak waarin 'n analiserende beskrywing van die prakties-teologiese situasie gebied word. Aan die hand van basisteoretiese perspektiewe word die normatiewe gesigspunte gestel, waarna veranderingstrategieë voorgestel word. Vanuit die Jakobusbrief word perspektiewe na vore gebring wat die noodsaak van goeie styl in die prediking benadruk. In die metateoretiese besinning word die kontoere van die Kunsgeskiedenis asook Kommunikasiekunde verken. In die praktykteoretiese perspektiewe wat bespreek word, word die ruimte wat stylvolle prediking moet skep, aangestip. Sodoende word dit benadruk dat enige styl nie noodwendig die korrekte styl is nie. 'n Goeie styl wend die regte woorde op die regte plekke in die preek aan en daarom is goeie styl eenvoudig en verstaanbaar.

Comprehensible preaching is simple preaching: A practical-theological reflection on preaching style. There is interdependence between preaching and transformation in the lives of hearers. There is a relationship of interaction and communication between preacher and hearers, exists in the act of preaching. When preachers open their mouths, style is used. Artists use colour in their paintings, but preachers use words to colour the content of their message. The research question for this investigation is therefore: What is the effect of an unclear style in sermons? The hypothesis for this research is that an unclear style in sermons does not change lives and fails to bring hearers into the presence of God. The research field is explored by coming to grips with the current practical theological situation. This article investigates certain meta-theoretical perspectives from the fields of Art History and Communication Skills. Basic-theoretical perspectives will be derived from the letter of James and normative vantage points will unfold. The researcher reaches the conclusion that good style creates a space in which hearers can communicate with God. A specific style of preaching is not necessarily the best style to use. Good style uses the correct words in the right places. Good style in a sermon makes preaching clear and comprehensible.

\section{Inleiding}

In resente navorsing word die intensie van prediking as ' $\mathrm{n}$ taal van hoop beklemtoon (Cilliers 2007:155-176; De Klerk 2007:177-202; Hermelink 2007:29-58; Vos 2007:11-28). Vroeër het Pieterse (2001:77-98) hom besig gehou met die navorsingsvraag van hoedanig die vertolking van 'n bybelse teks binne die konteks van armoede in Suid-Afrika tot verandering aanleiding kan gee. Nog vroeër het Craddock (1985:27) in sy besinning oor die beginsels van die prediking aangetoon dat prediking die gesprek van die teks met die hoorders as ' $n$ lewende en hoorbare stem moet bevorder. In hierdie proses moet die prediker duidelik en helder praat, sodat die hindernisse in die hoor van die Woord van God beperk kan word (Craddock 1985:64-65). Immink (2003:267) het prediking vanuit ' $n$ kommunikatiewe hoek beskryf as 'n gebeure van interaksie en kommunikasie tussen die prediker en die hoorder. Bogenoemde outeur kom op grond van sy navorsing tot die slotsom dat gelowiges weens hulle verhouding met God en met mekaar op diepgaande kommunikasie met mekaar aangewese is. In hierdie kommunikasieproses moet gelowiges seker maak dat hulle reg na mekaar luister en op die regte wyse met mekaar praat. Cilliers (2003:32-35) beskryf die aard van die kommunikasie deur aan te toon dat daar in die prediking gepraat word en dat die woord wat gevoer word, verteenwoordigend is van 'n vorm van kuns. Prediking as woordkuns kan volgens Cilliers (2003:32) op 'n beter, maar ook op 'n minder goeie wyse beoefen word. 
In navolging van Firet (1978:242), wat verandering die agogiese moment genoem het, is daar meermale in die navorsing gefokus op die doel van prediking, naamlik dat dit transformasie (verandering) moet bewerkstellig (vgl. Burger 1995:17; Kruger \& Venter 2006:54-69; Pieterse 2005:77-95; Venter 2001:515, 2005:217-237). Tot op hede is heelwat navorsing gedoen oor dit wat prediking beoog, naamlik verandering. Vanuit die beperkte seleksie van bronne wat met die oog op die artikel gedoen is, wil dit voorkom asof daar tog 'n leemte in die navorsing bestaan met betrekking tot die redes waarom prediking nie altyd die nodige uitwerking het nie. Cilliers (1996:93-113, 1998:19-21 en 2000:10-31) het wel in dié opsig kosbare navorsing gelewer waarin hy veral waarsku teen die gevaar van wettisisme wat prediking misvorm vanaf 'n uitwysing van God, na 'n uitwissing van God op die kansel.

Heelwat outeurs het ook vanuit 'n ekklesiologiese hoek besin oor die vraag of die kerk in 'n postmoderne era nog betekenis het (Vorster 1996:1; Nel 2003:151-196; Sweet 2007:22-25). Smith (2007:143) maak byvoorbeeld in dié verband die stelling dat die kerk in veranderende tye die hart van God deur sy Woord moet leer ken en verstaan, en dit dan op sigbare en duidelike wyse by gelowiges moet tuisbring. Lombaard (2007:12-15) het op sy beurt oor die kommunikasie binne die kerk opgemerk dat die rol van hoorders se sintuie onder die erediens optimaal benut moet word, en dat dit wat gesien en gehoor word veral van uiterste belang is. Kimball (2004:45) benadruk op sy beurt weer die daarstelling van 'n ruimte deur die handeling van prediking, sodat hoorders se deelname verhoog word. Cilliers (2008a:26) het in sy navorsing oor die daarstelling van die ruimte gewaarsku teen clichés wat die ruimte beperk. Clichés is woorde wat al stomp geword het vanweë die herhaalde gebruik daarvan en in die praktyk nie meer werklik gewig dra by die hoorders nie.

Vanuit 'n prakties-teologiese hoek wil hierdie artikel op tweeledige wyse vasstel of prediking nie moontlik vanweë 'n lomp of selfs 'n swak styl van sy krag beroof word nie, en ook aantoon dat verstaanbare prediking eenvoudige prediking is. Dit handel dus oor die navorsingsvraag of swak styl in die weg staan van prediking waarin God aan die woord moet kom en sodoende die effektiwiteit van prediking nadelig raak. Prediking moet God aan die woord laat kom en nou is die vraag of 'n slordige preekstyl nie die stem van God laat verstom nie. Onder styl word vir die doeleindes van hierdie artikel verstaan predikers se keuse van woorde vir hulle preke (Robinson 2001:184). Adams (1982:104) het bygevoeg dat predikers van die oomblik wanneer hulle begin praat 'n sekere styl gebruik. Daarom is die vraag nie of 'n prediker oor 'n styl beskik nie, maar of sy of haar styl goed of slordig is. Geen prediker kan argumenteer dat hulle nie die gawe van taal of van woorde het nie. Predikers word genoodsaak om in die kommunikatiewe handeling van die prediking van taal gebruik te maak (Robinson 2001:185).

Dingemans (1996:62) wys daarop dat die meeste praktiese teoloë deesdae drie dimensies in prakties-teologiese navorsing onderskei:
- die analiserende beskrywing van die prakties-teologiese situasie

- die ondersoek na normatiewe gesigspunte

- die ontwikkeling van veranderingstrategieë op grond van die beskrywing van normatiewe uitgangspunte.

Hierdie driedeling word ook in hierdie artikel gebruik, en daar word begin met ' $n$ analise van die praksis. Metateoretiese waarnemings word oor die ontstaan en funksionering van styl gemaak deur perspektiewe na vore te bring uit veral Kunsgeskiedenis en Kommunikasiekunde. Normatiewe gesigspunte word voorts bestudeer om basisteoretiese merkers te identifiseer wat vir die praksis van styl in die prediking van kardinale belang is, en daarna word praktykteoretiese perspektiewe aangebied.

\section{Wat is styl? Begripsverheldering en ' $n$ beperkte verkenning van homiletiese literatuur oor styl} 'n Beperkte verkenning van homiletiese literatuur

Indringende navorsing is reeds gedoen oor die skeppende krag van woorde en die belangrikheid van taalhandelinge. Die belangrikheid daarvan dat die bybelse teks in die erediens juis deur spreektaal en lyftaal gekommunikeer word, is sodoende benadruk (Hermelink 2007:44). Dingemans (1991:140-141) het die uitdaging van die prediking beskryf as 'n poging om die afstand tussen die verhaalkultuur en die hedendaagse leeskultuur te oorbrug. Op die voetspoor van Paul Ricoeur toon Dingemans (1991:141) aan dat hoorders graag tekste hulle eie wil maak. Dit is daarom noodsaaklik dat prediking as kommunikasiemiddel die hoorders hierin sal begelei. Predikers moet 'n kommunikasieveld vir die hoorders open sodat hulle aan die hand van die bybelse teks met God kan kommunikeer (Dingemans 1991:151). Vos (1996:122-167) bied 'n uitgebreide oorsig aan oor die rol van kommunikatiewe handelinge soos deur Jürgen Habermas bepleit en die insigte van die taalhandelingsteorie. Die navorsing in dié verband het dit beklemtoon dat daar deur taal gehandel word en dat dié handeling 'n effek het (Vos 1996:122). Die uitspraak van Lange (1987:58), 'Mein Thema ist mein Hörer', is alombekend in die Praktiese Teologie. Met hierdie uitroep wou hy die prediking bevry van abstraksie wat los van die Woord en los van die werklikheid is.

Woorde is dus belangrik en daarom is dit belangrik om woordbewus te wees (Capps 1981:10). Bingle (1987:2-8) het die woordbewustheid van die prediking beskryf as 'n taal- en vertaalgebeure. Prediking wat God se Woord vir hoorders verstaanbaar maak, is aangewese op woorde (Bingle 1987:3). Dit wat kleur vir 'n skilder is, is woorde vir predikers (Robinson 2001:184). Pieterse (1985:116) druk die verantwoordelikheid van predikers ten opsigte van die woordbewustheid uit deur te sê dat predikers nie die boodskap van die Woord in hemelse tale uitdruk nie, maar in gewone alledaagse taal. Dit is vanselfsprekend dat dit so moet geskied dat die gemeente sal verstaan. Bogenoemde 
beredenering kan moontlik die indruk skep dat 'n preekstyl 'n kunsmatige en aangeleerde saak is. Daarom waarsku Pieterse (1985:117) heeltemal tereg teen 'n geaffekteerde preekstyl waardeur predikers, soos hy dit stel, met woorde 'n dop om hulle persoonlikheid vorm. Predikers mag nie in hulle preekstyl woorde gebruik wat wesensvreemd aan hulle eie ervaring en persoonlikheid is nie en sodoende die kontak met hulleself verloor nie. Die woordgebruik van predikers moet eg en opreg wees.

Adams (1982:104) onderstreep die uitwerking van die styl van ' $n$ prediker deur te benadruk dat dit nie neutraal is nie. 'n Preekstyl kan hoorders óf in die verstaanproses help, óf as ' $n$ hindernis dien. Vir Adams (1982:105) is 'n goeie styl 'n eenvoudige en duidelike styl wat nie die aandag op die prediker vestig nie. Die inhoud van die preek en teks is daarom vir bogenoemde outeur van kardinale belang. Craddock (1985:196) het in hierdie verband opgemerk dat indien predikers 'n goeie preekstyl het en op hulle woordkeuses let, dit baie van die kritiek teen prediking wegneem. Die keuse van woorde en die hantering van styl moet volgens Craddock (1985:197) die effek van die teks in hoorders se lewens dien en wakker maak. Robinson (2001:185) voer die saak verder en maak 'n saak daarvoor uit dat predikers se styl noodwendig van gehoor tot gehoor sal verskil. Hoorders het boonop nie die gerief om onder die prediking die woorde van predikers terug te speel om agter die kap van die byl te kom nie (Robinson 2001:186). Daarom moet predikers se styl, oftewel hulle woordgebruik, duidelik en eenvoudig wees. Die klem wat navorsers op woordbewustheid plaas, bring daarom 'n noodsaaklikheid na vore om verder te besin oor die aanwending van styl in die prediking.

\section{Begripsverheldering}

Die verklarende woordeboek van die Afrikaanse taal (WAT) (Odendal 1995:1044) bied onder andere die volgende verklaring van styl aan: dit kan dui op 'n steunpaal, 'n deurpos, die trant of wyse van skryf of die bepaalde wyse van uitdrukking van 'n bepaalde kunstenaar.

Die prediker se styl het te make met woordkeuse of die vloei van gedagtes waardeur die momente van die preek as uitleg en toepassing van die Woord van God met die gemeente gekommunikeer word. Die prediker se styl kan vir hoorders óf ' $n$ steunpilaar óf ' $n$ hindernis wees. Daar word vervolgens aandag gegee aan die hermeneutiese wisselwerking tussen die metateorie en basisteorie.

\section{Metateoretiese perspektiewe oor die begrip styl}

In die ontginning van metateoretiese perspektiewe sal hoofsaaklik eklekties te werk gegaan word. Hiervolgens sal toepaslike materiaal uit die dissiplines van Kunsgeskiedenis en Kommunikasiekunde deur middel van analise en interpretasie gekeur en gerangskik word om in te pas in die opset van hierdie navorsing.

\section{Metateoretiese perspektiewe vanuit die Kunsgeskiedenis}

Die verhouding tussen religie en kuns het 'n lang en soms stormagtige geskiedenis (Cilliers 2003:18). Die kerk was vir 'n lang tyd as 't ware die beskermheer van alle vorme van kuns, maar ook vir 'n baie lang tyd 'n opponent van die kuns (Cilliers 2003:18). Kuns het egter ook volgens Cilliers (2003:18) al as katarsis gedien vir die bekendmaking van die verskillende dimensies van die geestelike lewe. Reierson (1988:7-10) het byvoorbeeld aangetoon dat die kuns 'n vermoë het om godsdienstige betekenis en vrae te kommunikeer. In daardie sin van die woord kan kuns ook teologie word, omdat dit die teologie help om groter insig in die werklikheid te verkry (Cilliers 2003:19). Bogenoemde outeur verwys met waardering na die bydrae van Reierson (1988:28-29) wat die stelling maak dat kuns oral en om alle mense is en dat ook predikers veel kan leer by kuns.

Die woord styl is volgens Honour \& Flemming (2002:25) afgelei van die woord stylus. 'n Stylus was 'n instrument wat die Romeine gebruik het om mee te skryf. Gaandeweg is die woord ook metafories begin gebruik om 'n aanduiding te wees van die verskillende maniere waarop sprekers verskillende gehore toespreek (Flemming 1996:18). Vanuit die Kunsgeskiedenis wil dit voorkom asof die begrip styl gebruik is as aanduiding vir die werke van kunstenaars asook vir die werke van kunstenaars binne 'n bepaalde tyd en gebied (Honour \& Flemming 2002:25). Kunstenaars oefen die keuse uit om 'n sekere medium te gebruik, hulle gebruik sekere tegnieke en selfs sekere woorde, en alles is deel van 'n kunstenaar se styl (Arnason 1996:18-19). 'n Styl is iets wat eie is aan 'n kunstenaar se gebruik van mediums. 'n Bepaalde styl het ook die neiging om geïnternaliseer te raak binne ' $n$ bepaalde omgewing en tydsgewrig, vanweë die feit dat kunstenaars blootgestel word aan dieselfde kulturele erfenis en dit dan 'n vertrekpunt word vir hulle kuns (Flemming 1996:18). Kuns openbaar ook die tendens dat daar konserwatiewe kunstenaars is wat sekere waardes met hulle kuns wil beskerm, sowel as liberale kunstenaars wat uitdrukking wil gee aan huidige tendense en die tendense van die toekoms wil antisipeer (Flemming 1996:19).

Kuns het daarom 'n unieke taal (Arnason 1996:9). Kunstenaars wil met hulle kunswerke uitdrukking gee aan dieper oortuigings en gevoelens. Hierdie oortuigings kan getuig van aanvaarding of verwerping, saamleef of protes, konformeer of hervorm, droom van die verlede of profeteer oor die toekoms (Flemming 1996:19). Tyd, plek en idee is die drie kernbegrippe in die kuns wat meebring dat daar dikwels ooreenstemming in styl by kunstenaars is, tesame met eie aksente (Honour \& Flemming 2002:25). Hieruit blyk dit dat 'n kunstenaar se moeite met 'n bepaalde styl daartoe kan bydra dat ander kunstenaars beïnvloed word en dat dit dan aanleiding kan gee tot ' $n$ vernuwing in die kuns. Dit bring mee dat ' $n$ bepaalde styl 'n woordeskat van sy eie het wat enersdenkende kunstenaars in 'n eenheid saamsnoer.

Kunstenaars gebruik egter verskillende style vir verskillende sosiale teikengroepe en met die oog op verskillende doelwitte (Honour \& Flemming 2002:25). Kunstenaars gebruik 
byvoorbeeld verskillende style vir persone wat op meer rasionele manier na kunswerke kyk en persone wat van die populêre en meer alledaagse kunswerke hou (ibid. 2002:18). Verskillende style in kuns het dikwels ook na vore getree as gevolg van 'n verandering in godsdienstige oortuigings en waardes in die samelewing (Flemming 1996:20). Bogenoemde outeur maak daarom die gevolgtrekking dat kunstenaars met hulle styl as hulle eiesoortige taal probeer om sin te gee aan die werklikheid van die samelewing. Cilliers (1998:38-39) toon aan dat kunstenaars oral en altyd skep. Dit wat waargeneem word, word in die sisteem van die geheue gestoor, 'n sisteem wat inligting rangskik. Die kunswerk word in hulle oë gebore en daarom is die uitvoering van die kunswerk eintlik 'n afronding van die waarnemingsproses (Cilliers 1998:39). 'n Kunstenaar sonder oë is daarom nie 'n kunstenaar nie (Arnason 1996:312).

\section{Metateoretiese perspektiewe vanuit die Kunsgeskiedenis}

Die volgende perspektiewe vanuit die Kunsgeskiedenis kan as merkers dien vir 'n verdere besinning oor styl:

- Prediking en Kuns het baie met mekaar in gemeen. Prediking is kuns met woorde en liggaamstaal. Kunstenaars gebruik 'n sekere styl om mense se denke te beïnvloed. Predikers moet daarom bewus wees van die rol van styl in die gebruik van woorde. Die taal as styl moet hoorders uitnooi na die wêreld van die bybelse teks wat alles te make het met die werklikheid.

- Soos kunstenaars mekaar se style beïnvloed, kan predikers in dieselfde omgewing en tyd mekaar beïnvloed. Dit kan ten goede geskied, maar 'n slordige styl kan ook by ander predikers aangeleer word.

- 'n Kunstenaar se styl onderskei hom van ander, maar is ook 'n aanduiding van die skool waarin hy hom bevind. Predikers se styl onderskei hulle teologies en ook as persoon van ander predikers, en is terselfdertyd ' $n$ aanduiding van die stroom waarin hulle hulleself bevind.

- 'n Kunstenaar se styl ontbloot die oë waardeur hy of sy na die werklikheid kyk. 'n Prediker se styl ontbloot die oë waardeur hy of sy na die Woord, die gemeente en die werklikheid kyk. Styl is daarom die manier waarop die prediker die werklikheid met woorde inkleur.

- Kunstenaars gebruik verskillende style vir verskillende teikengroepe en omstandighede. Predikers moet moeite doen met 'n kreatiewe styl.

- Met sy styl wil 'n kunstenaar 'n boodskap oordra. Predikers wil ook met hulle styl 'n boodskap oordra en daarom is metaforiese taal van onmisbare belang. Die taal van die Bybel moet met keurige en eenvoudige alledaagse taal ontsluit word.

\section{Metateoretiese perspektiewe vanuit die Kommunikasiekunde}

Pieterse (1987:72, 2005:77-95) het in sy navorsing herhaalde kere onderstreep dat dit in die Praktiese Teologie om kommunikatiewe handelinge in diens van die evangelie gaan. Vos (2007) het selfs daarvoor gepleit dat prediking, as 'n vorm van kommunikasie, hande, voete, oë en ore sal kry wat hoorders sal raak. In hierdie opsig het Praktiese Teologie ook 'n raakvlak met Kommunikasiekunde. Dit is daarom noodsaaklik dat Praktiese Teologie met Kommunikasiekunde in gesprek sal tree vanweë albei se belangstelling in die hoorder. Die nadenke oor styl in prediking het immers direk te make met die wyse van kommunikasie met die hoorders. Pieterse (1987:72) betreur dit dat baie predikers sukkel om die boodskap van die bybelse teks in verstaanbare taal te bring, juis omdat hulle dikwels nie vertroud is met die leefwêreld van hulle hoorders nie. Die insigte van Kommunikasiekunde verskaf 'n goeie raamwerk waarbinne besin kan word oor die styl van prediking.

Huebsch (1995:70) benadruk die feit dat die styl van 'n toespraak doelmatig en presies moet wees. 'n Goeie kommunikator gebruik altyd toepaslike taal ooreenkomstig die situasie waarin hy homself bevind. In die tegniese wêreld moet 'n spreker byvoorbeeld die tegniese terminologie bemeester, hom oefen in toepaslike woordeskat en uitdrukkings om toepaslike inligting op doelgerigte wyse oor te dra (Huebsch 1995:70). Sprekers moet 'n doeltreffende styl aanwend wat pas by elke gehoor.

Goeie kommunikeerders is bedag op slagysters soos onnodige herhaling, breedsprakigheid, omslagtigheid en vae en niksseggende uitdrukkings en woorde. Pieterse (1985:115-116) meen dat omslagtigheid wel soms 'n opbouende doelwit het, byvoorbeeld wanneer sprekers in 'n toespraak of preek ou, bekende taal kombineer met nuwe taal of stof wat aangeleer moet word. In hierdie sin van die woord word die oortollige stof (die ou en bekende terminologie) as voertuig gebruik om die nuwe begrippe mee te vervoer. Dit help hoorders om 'n assosiasie te maak. 'n Verdere hulpmiddel wat Pieterse (1985:115) onderskei, is die reëlmaat en ordelikheid van struktuur. Inligting het met ander woorde 'n raamwerk nodig waarbinne dit moet funksioneer. Goeie orde in taalgebruik is van onskatbare belang in kennisoordrag.

Moeilike begrippe en woorde kan verduidelik word deur meer woorde te gebruik om die saak mee te verduidelik. Deur middel van taal en die ordelike manier waarop dit gebruik word, moet die nuutheid van die boodskap immers oorgedra word (Pieterse 1985:116).

Huebsch (1995:70-79) onderskei die volgende beginsels wat goeie styl sal bevorder:

- Duidelikheid (helderheid): slordige en onduidelike taalgebruik is ' $n$ hindernis vir hoorders. Abstrakte woorde kan hoorders verwar. Alhoewel oorvereenvoudiging van woorde 'n probleem ten opsigte van goeie kommunikasie kan skep, bevorder eenvoudige woorde meestal kommunikasie.

- Eenvoud: feite, konsepte en gedagtes moet eenvoudig oorgedra word. Die aanwending van byvoeglike naamwoorde en bywoorde moet toepaslik en eenvoudig wees.

- Natuurlikheid en spontaneïteit: natuurlike en spontane taalgebruik is as 'n reël duidelike taalgebruik. Sprekers 
moet daarop let dat tegniese begrippe 'n stoornis kan veroorsaak, veral by die hoorders wat stadig van begrip is.

- Bondigheid: sprekers moet egter daarteen waak om hulle boodskap te oorvereenvoudig. Sleng moet vermy word, asook vaktaal en vakterminologie wat nie aan almal bekend is nie.

- Clichés: vanweë die feit dat dié tipe woorde so gereeld en algemeen gebruik word, het die impak en krag daarvan verlore gegaan.

- Die weglating van belangrike woorde en begrippe. Sekere woorde en begrippe is van kardinale belang in sinvolle kommunikasie. Aan die ander kant moet woorde wat nie waarde toevoeg nie, wel weggelaat word.

- Veralgemening: veralgemening skep 'n negatiewe gesindheid by hoorders.

- Konkreetheid: konkrete woorde maak kommunikasie helder.

- Diskreetheid: sprekers moet waak teen diskriminerende woorde. Sprekers trap dikwels in die slaggat om, sonder dat hulle dit noodwendig so bedoel, diskriminerend oor te kom ten opsigte van ouderdom, beroep, ras, ensovoorts.

- 'n Positiewe styl in kommunikasie: negatiewe kommunikasie skep afstand tussen die spreker en die hoorder.

- Sprekers moet let op die samestelling van sinne: sinne wat nie sin maak nie, moet herformuleer word. Oorgange tussen gedagtes en paragrawe moet organies, gemaklik en verstaanbaar wees. Hoorders luister makliker na boodskappe wat logies oorkom.

Den Dulk (1995:14) het die noodsaak van duidelike kommunikasie onderstreep deur die rol van hoorders te beskryf as 'n hoorgemeenskap wat deur die loop van die toespraak (preek) self in 'n praatgemeenskap verander. Vos (1996:188) het in sy besinning oor 'n dialogiese model vir die prediking by Den Dulk aangesluit deur te benadruk dat die ecclesia audiens moet verander in die ecclesia docens. Habermas (1992:440) asook Keulartz (1992:274), het 'n duidelike saak daarvoor uitgemaak dat mense deur middel van kommunikatiewe handelinge aangemoedig moet word om mekaar te ontmoet en te dien. Zerfass (1989:70-72) het aan die hand van die begrippe assosiasie en bisosiasie probeer verduidelik dat die sprekers (predikers) hulle moet inspan om die teks vanuit die hoek van die hoorders te sien, aangesien dit ' $n$ toespitsing op die konkrete situasie moontlik maak. Bogenoemde beredenering vanuit die Kommunikasiekunde is vir die prediking van belang, aangesien dit benadruk dat die wyse waarop predikers hulleself uitdruk, bepalend is vir die transformering van 'n hoorgemeenskap in 'n praatgemeenskap.

\section{Metateoretiese perspektiewe op die begrip styl vanuit die Kommunikasiekunde}

Die volgende perspektiewe vanuit die Kommunikasiekunde kan moontlik die verdere gesprek oor styl tot voordeel strek:

- Predikers moet bedag wees op die belangrikheid van goeie styl in hulle prediking. Predikers moet moeite doen om hulle hoorders te begryp en hulle styl aanpas by die begrips- en belewingswêreld van hulle hoorders.
- Predikers moet hulle oefen in die aanleer van toepaslike woordeskat en moeite doen om wanneer hulle preke skryf, dit so te skryf dat dit die boodskap effektief kommunikeer.

- Daar bestaan talle slaggate in die hantering van styl wat dit vir hoorders moeilik maak om God te ontmoet.

- Predikers moet langs die weg van eksegese, hermeneuse en homilese duidelik onder die indruk kom van wat hulle presies in die lig van die Woord wil kommunikeer. Hierdie boodskap moet dan in duidelike en eenvoudige taal gekommunikeer word.

- Enige woord of begrip is op sigself nie goed genoeg vir 'n preek wat gelewer word nie. Die beste woorde en beste begrippe wat vir die hoorders duidelik is, moet gebruik word.

- Die prediker se taalgebruik mag nie so kunsmatig wees dat hulle preektaal geen raakpunte met alledaagse omgangstaal het en dus onverstaanbaar vir die meeste hoorders is nie.

- Indien predikers nie seker is of hoorders hulle taalgebruik verstaan nie, moet hulle meer verduidelikende woorde en begrippe inspan om hoorders se taak te vergemaklik.

- Predikers se styl kan hulle boodskap verhelder, maar ook verduister. Hoorders moet met die hulp van sinvolle en keurige styl gehelp word om met God in gesprek te tree.

\section{Basisteoretiese perspektiewe oor die styl van predikers Algemene retoriese eienskappe in die Nuwe}

Nida, Louw, Snyman en Cronje (1983:23-27) het in hulle navorsing sekere retoriese eienskappe in die Nuwe Testament aangetoon. Hulle onderskei veral vier hoofgroepe, naamlik herhaling, weglating, 'n verskuiwing in verwagtings en kompaktheid. Bogenoemde outeurs toon op grond van hulle navorsing aan dat hoorders in die kommunikasie-situasie 'n retoriese kompetensie ontwikkel. Hiermee bedoel hulle dat hoorders baie vinnig agterkom of 'n preek goed en stylvol aangebied word. Op grond hiervan word retoriese samewerking verkry, al dan nie (Nida et al. 1983:51). Robinson (2001:187-189) bemerk ook in die preke in die Bybel 'n poging om duidelik en eenvoudig te wees. Traugott en Pratt (1980:229-231) en Vos (1996:122-124) het daarop gewys dat die insigte van die taalhandelingsteorie nie in die prediker se styl buite rekening gelaat moet word nie. Bogenoemde outeurs vestig die aandag op die lokutiewe (grammatikale) aksie, die illokutiewe aksie (kommunikatiewe doelwit) en die perlokutiewe aksie (die effek van die kommunikasie) van 'n taalhandeling. Daarom kan die rol van die retoriek nie buite rekening gelaat word nie. Die term retoriek soos dit hier gebruik word, dui op die manier waarop taal gebruik word om op 'n doelgerigte taalhandeling te fokus. Retoriek is die doelbewuste poging van 'n spreker of prediker om oorredend op hoorders in te werk (Vos 1996:124). Leech (1989:8) toon aan dat daar veral vier soorte grondreëls onderskei moet word in hierdie kommunikasie. Vos (1996:126) plaas op grond hiervan die klem op dit wat meermale as die koöperatiewe beginsel in gesprekvoering beskou word. Die vier sake wat as koöperatiewe beginsel dien, is: 
- Kwantiteit: hiermee word bedoel dat predikers die regte hoeveelheid inligting moet verskaf.

- Kwaliteit: slegs dit wat waar en in ooreenstemming met die Skrif is, moet verkondig word.

- Daar moet relevansie in preke wees. Preke moenie ruimtes van vaagheid en aanvegbaarheid bevat nie.

- Die preekaanbieding moet helder wees.

Hierbenewens het Leech (1989:132) ook 'n hoflikheidsbeginsel onderskei wat in kommunikasie onderhou moet word. Hiermee word bedoel dat predikers in die prediking hulle hoorders in ag moet neem. Die grondreëls wat die hoflikheidsbeginsel ondersteun, is takt, 'n ruimhartigheid wat meebring dat die behoeftes van hoorders aandag kry; 'n soeke na die instemming van die hoorders, beskeidenheid en nie oormoedigheid nie; 'n ooreenstemming tussen die Woord en die situasie; en bewyse van begrip en deernis vir die hoorders.

\section{Basisteoretiese perspektiewe op die styl van die Jakobusbrief: Is die Jakobusbrief 'n brief of 'n preek?}

Basisteoretiese perspektiewe word in hierdie onderafdeling vanuit die Jakobusbrief ontgin. Die brief van Jakobus bied bepaalde merkers aangaande die aanwending van styl in die prediking. Kistemaker (1992:4) het in sy navorsing oor die brief beklemtoon dat die getuienisbrief ook as 'n preek beskou kan word, nie buite rekening gelaat mag word nie. Hiervolgens sou die pastoor Jakobus, 'n aantal preke vanuit Jerusalem aan die kerk in diaspora gestuur het, sodat dit tydens eredienste voorgelees kon word (Kistemaker 1992:4). Tasker (1977:9) ondersteun hierdie siening, en beskryf die brief as vol preeknotas. Predikers moet in hulle preke en in die aanwending van styl kennis neem van die doelgerigte woordekonomie in die brief (Tasker 1977:10). Tasker (1977:38) toon selfs aan dat die moontlikheid bestaan dat Jakobus se preke in die vorm van ' $n$ brief (wat in die Bybel as die brief van Jakobus opgeneem is) gegiet is. Pretorius (1988:15-16) toon op sy beurt aan dat die Jakobusbrief Hellenistiese formulerings bevat wat mettertyd in ' $n$ Joodse milieu ingeburger geraak het. Verder bemerk bogenoemde outeur ook 'n ooreenkoms met die bekende diatribe-styl wat gebruik gemaak het van 'n argumentasie-styl. Hierdie diatribe-styl laat Pretorius (1988:16) ook dink dat preekstof in die vorm van 'n brief in die Jakobusbrief aangetref word. Daar word boonop selfs iets van 'n literêre gespletenheid in die brief bemerk deurdat goeie Griekse taalgebruik afgewissel word met semitismes en wisselterme (Pretorius 1988:16). 'n Hipotese sou dus kon wees dat sommige van Jakobus se preke later in briefvorm geredigeer is.

Ander outeurs het, sonder om die Jakobusbrief as 'n preek te bestempel, die andersheid van die brief benadruk. Vroeër het Gundry (1970:343) besin oor die uniekheid van hierdie boek en aangetoon dat dit nie as 'n dogmatiese brief geskryf is nie, maar een van die mees praktiese boeke in die Nuwe Testament is. Martin (1988:1-55) bemerk ook in die Jakobusbrief 'n geneigdheid om prakties en motiverend daartoe by te dra dat hoorders verander. Volgens Martin (1988:1-55) maak
Jakobus in die proses van keurige taal gebruik. Douglas (1986:550) noem die Jakobusbrief nie 'n preek nie, maar maak melding van die homiletiese eienskappe daarvan.

Kistemaker (1992:4) bied die volgende redes aan waarom die Jakobusbrief volgens hom ook as 'n brief met die eienskappe van 'n preek beskou kan word:

- Die Jakobusbrief bestaan uit twee gedeeltes (preke), naamlik hoofstuk 1-2 en hoofstuk 3-5. Die twee dele bestaan amper uit dieselfde aantal woorde, naamlik 43 en 45 onderskeidelik.

- Die eerste preek handel oor die geloof en die tweede preek handel oor die belangrikheid om te let op dit wat jy sê.

- Die Jakobusbrief vertoon ooreenkomste met preke uit die vroeë kerk. Die preke uit daardie era het gebruik gemaak van 'n dialogiese styl en die gebruik van die aanspreekvorm broeders. Een preek het ook 'n verskeidenheid sake bespreek.

Moontlik kan die saak opgesom word deur te sê dat die brief inderdaad vanweë die aanhef en groete aan die begin ' $n$ brief is, maar dat dit tog sekere eienskappe het wat eie is aan 'n preek. Vanweë die feit dat sekere homiletiese kontoere hierin vervat is, is dit wenslik dat perspektiewe vanuit die brief verder ontgin word.

\section{Die aanwending van styl in die Jakobusbrief}

Volgens Kistemaker (1992:5-6) kan die volgende eienskappe van goeie styl in die Jakobusbrief onderskei word:

- Die Griekse taalgebruik is, net soos dié in die brief aan die Hebreërs, van 'n hoë standaard. Alhoewel goeie Grieks gebruik word, het die inhoud 'n sterk Joodse kleur. In die brief word dikwels gebruik gemaak van parallelismes. Voorbeelde hiervan word in Jakobus 1:9-10, 1:15 en 17, 1:19-20, 1:22-23, 2:22, en 4:7 en 10 aangetref. In hierdie opsig het Coetzee (1988:22-24) aangetoon dat predikers en skrywers praat en skryf sodat hulle verstaan kan word. Daarom is dit noodsaaklik dat struktuurmerkers wat bewustelik of selfs onbewustelik deur 'n Bybelskrywer gebruik is om beter te kommunikeer, raakgesien word. Strukturering van preke is volgens Coetzee (1988:24) dikwels die verskil tussen effektiewe en oneffektiewe predikers. Bybelskrywers wou, net soos hedendaagse predikers wil, hulle boodskap struktureer en sodoende iets by hoorders opwek. Met parallelismes word woorde, sinne en frases in 'n verhouding geplaas waarin hulle met mekaar ooreenstem.

- Die Jakobusbrief maak van 54 imperatiewe gebruik. Die aanwending van die bevelsvorm benadruk ' $n$ verhouding tussen die skrywer en die lesers wat getuig van gesag, maar ook van 'n deernis om die lesers pastoraal te begelei in hulle lewenskonteks.

- Die skrywer van die Jakobusbrief maak dit vir sy lesers maklik om die vloei van sy gedagtes te verstaan deur gebruik te maak van talle voorbeelde en vergelykings uit die natuur en die alledaagse lewe. Die beelde wat gebruik word, spreek boekdele: wind en die golwe van die see, die opkomende son en hitte wat verskroei, iemand wat in 
'n spieël kyk en vergeet wat hy gesien het, die tong wat met vuur vergelyk word. Met hierdie beelde behou die skrywer deurlopend die aandag van sy lesers. Die gebruik van beelde benadruk ook die feit dat die skrywer nie tred met die werklikheid verloor het nie.

- Die Jakobusbrief verbind sinne op deurlopende wyse deur gebruik te maak van die tegniek van herhaling. Die laaste woord van ' $n$ sin word die eerste woord van 'n nuwe sin (vgl. Jak 1:2-4).

\section{Basisteoretiese perspektiewe op die styl in die Jakobusbrief met verwysing na enkele perikope}

Pretorius (1988:22-23) toon aan dat die woordgebruik in die Jakobusbrief hamartologies, maar ook soteriologies van aard is. Die skrywer skroom nie om in die lig van die Woord sekere sake as sonde uit te wys nie, maar doen dit teen die agtergrond van die verlossing in Christus. Kistemaker (1992:11-13) toon aan dat die Jakobusbrief duidelike ooreenkomste toon met Jesus se Bergpreek. Jakobus sluit dus in sy brief aan by die boodskap van Christus. Dit wat Jakobus wil sê, het dus 'n gesagsbasis, naamlik die woorde van Jesus Christus (Kistemaker 1992:11). Dit is verder opmerklik dat die koöperatiewe beginsels van gesprekvoering soos in die retorika onderskei (vgl. algemene retoriese eienskappe in die Nuwe Testament), naamlik kwantiteit, kwaliteit, relevansie en helderheid, in die Jakobusbrief op uitnemende wyse tot hulle reg kom. Die hoflikheidsbeginsel (vgl. algemene retoriese eienskappe in die Nuwe Testament) wat dui op die wyse waarop die prediker met die hoorders omgaan, word in die Jakobusbrief op taktvolle wyse hanteer. In dié artikel is reeds aangedui dat die styl van prediking dui op die wyse waarop 'n prediker se gedagtes vloei en hy of sy woorde gebruik. Daar word nou 'n seleksie vanuit die Jakobusbrief gedoen om hierdie onderskeiding basisteoreties te toets.

\section{Basisteoretiese perspektiewe vanuit Jakobus 1:2-8}

In Jakobus 1:2-8 word die veelkleurige en veelvormige arsenaal van teenslae en swaarkry in gelowiges se lewens onder die vergrootglas geplaas (Pretorius 1988:34). Die lesers van die Jakobusbrief het vervolging en swaarkry as gelowiges baie goed geken (Martin 1988:14). Nadat die skrywer sy lesers as broeders aangespreek het en hom daarmee met hulle vereenselwig het, gee hy die opdrag dat hulle baie bly moet wees wanneer hulle allerhande

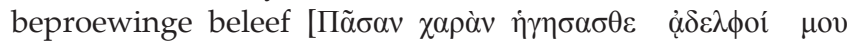

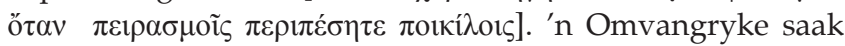
word op woordekonomiese wyse aangespreek. Die aoristusimperatief, naamlik $\dot{\eta} \eta \sigma \alpha \sigma \theta \varepsilon$, het die betekenis van 'oorweeg of bedink' en kan selfs op "n doelbewuste en weldeurdagte oordeel' dui (Kistemaker 1992:36). Louw en Nida (1993:365) plaas die begrip in die semantiese veld van 'om 'n opinie te hê of om van oortuiging te wees'. Hierdie opdrag om bly te wees is nie werklikheidsvreemd nie, aangesien die opdrag ook elders in die Nuwe Testament weerklank vind (vgl. Rom 5:3 en 1 Pet 1:6). Die woorde van Jesus in die saligsprekinge, soos in Mattheus 5:11-12 en Lukas 6:22-23 opgeteken, vind ook in hierdie opdrag weerklank.

Die opdrag om oor beproewinge bly te wees, word vergesel van 'n byvoeglike naamwoord wat veral in die kunswêreld

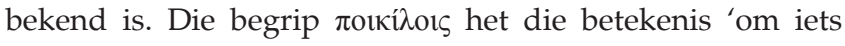
bont te verf, of om van veelkleurigheid gebruik te maak' (Martin 1988:15). Die begrip veelkleurigheid is met oorleg gekies om die veelkantigheid en verskillende dimensies van beproewing te benadruk (Tasker 1977:40). Benewens die veelseggende en sprekende woordeskat is die alliterasie van die konsonant $\pi$ ook opvallend. Die drie woorde $\pi \varepsilon \iota p \alpha \sigma \mu$ ĩ $\varsigma$,

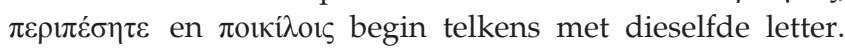
Die skrywer openbaar hiermee die feit dat die woorde selfs op klankwaarde doelbewus gekies is om die saak te benadruk (Kistemaker 1992:36). Om die produktiewe aard van beproewings op die geloofslewe te benadruk, gebruik Jakobus weer eens 'n duidelike werkwoord, naamlik

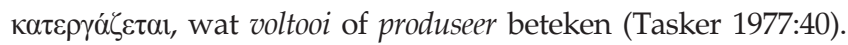
Jakobus giet hierdie produktiewe werking van beproewings in gelowiges se lewe in Jakobus 1:3-5 in die vorm van 'n eksplisiete trapleerkomposisie. Die laaste woord van elke vers vorm die beginwoord en begingedagte van die volgende vers. Hierdie trapleerkomposisie vorm ' $n$ merker vir die lesers om die boodskap duidelik te eien. Die styl van Jakobus word verder verryk met metaforiese taal, naamlik 'n beeld van 'n brander in die see wat deur die wind aangejaag word. Die styl van Jakobus se prediking verryk sodoende die inhoud van sy boodskap. Die styl maak Jakobus se woorde duidelik en eenvoudig en begelei hoorders op 'n metaforiese wyse om die landskap van die beheersing van die tong te verken.

\section{Basisteoretiese afleidings uit Jakobus 1:2-8}

Die volgende afleidings kan vanuit bogenoemde gedeelte gemaak word:

- Jakobus gebruik veelseggende woorde wat presies sê wat hy bedoel wanneer hy die moeilike saak van beproewings ter wille van die geloof bespreek.

- Eenvoudige en veelseggende woordeskat (grammatika) word verryk met kreatiewe struktuurmerkers en stylfigure. Jakobus giet sy boodskap in 'n bepaalde vorm wat pas by sy boodskap.

- Woorde en struktuurmerkers word ook in die Jakobusbrief gekomplementeer deur duidelike beeldspraak. Hieruit blyk die definitiewe kommunikatiewe doelwit van die skrywer.

- Die wyse waarop styl aangewend word, moet bepaal word deur die inhoud van die prediking. Woorde moet dien as 'n eenvoudige en maklike toegang tot die inhoud van die preek.

\section{Basisteoretiese perspektiewe uit Jakobus 3:1-12}

In Jakobus 3:1-12 word die gebruik van die tong en die dissipline wat hierin benodig word, bespreek (Kistemaker 1992:105). Dit is opvallend dat wanneer Jakobus met gelowiges praat wat leermeesters is, hy sy styl op 'n lewendige en byna poëtiese wyse inkleur (Pretorius 1988:73). Op lewendige wyse word die rol van die tong beskryf, sowel op positiewe as negatiewe maniere. Pretorius (1988:73) bemerk selfs in die manier waarop Jakobus 3:1-12 en Jakobus 3:13-18 naas mekaar geplaas word, ooreenkomste met die styl van die wysheidsliteratuur wat in daardie tyd alombekend was. Die bekende beelde van 'n perd met 'n stang in die bek, 'n skip 
met 'n roer en 'n vuur wat klein begin maar vernietigend kan eindig, word op kunstige wyse ingespan om die boodskap te versterk. Die drie beelde benadruk die besef dat, indien iemand weet hoe om 'n perd te stuur, die roer van 'n skip te hanteer en met vuur te werk, hulle almal 'n nuttige funksie het.

Die beelde word egter gekontrasteer met die werklikheid waarin gelowiges hulleself bevind (Kistemaker 1992:112). Deur gebruikmaking van ironie waarin verwys word na alle diere, voëls en seediere wat al deur die mens as heerser getem is, beklemtoon Jakobus die mens se verantwoordelikheid en magteloosheid ten opsigte van sy tong (Tasker 1977:77). Selfs wanneer Jakobus die inhoud van mense se woorde as gif beskryf, gebruik hy die woord wat na 'n slang se gif verwys (Pretorius 1988:77). Deur die gebruik van eenvoudige en toepaslike beelde, maak hy seker dat die essensie van sy boodskap begryp word.

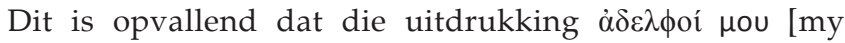
broers] met die aanvang van die saak wat bespreek word, gebruik word. Volgens Kistemaker (1992:106-107) identifiseer Jakobus nie alleen in die aanspreekvorm met sy lesers nie, maar ook in die gebruikmaking van die eerstepersoonmeervoudsvorm (ons). In die bespreking wat volg, voeg Jakobus hom met die gebruik van ons by sy lesers. In al die gevare wat Jakobus bespreek, beskou hy hom as deel van die verstrooide gemeente en spreek hy dus nie 'n koue oordeel of veroordeling oor die gemeente uit nie. Volgens Tasker (1977:73) loop alle predikers die gevaar om in die uitwys van gelowiges se sonde hulleself te wil regverdig. Kistemaker (1992:107) wys daarop dat Jakobus hom hiermee as 'n simpatieke pastor bewys wat weldeurdagte woorde gebruik om dit wat hy op die hart het, van sy hart af te kry.

In Jakobus 3:6 word die ontwikkelingsprogressie van 'n vuur verduidelik. Jakobus gebruik hiervoor 'n woord wat die

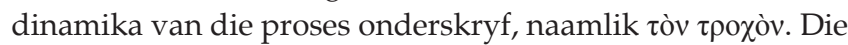
begrip word slegs een maal in die Nuwe Testament gebruik en wel in Jakobus 3:6 (Kistemaker 1992:114). Hierdie woord is ontleen aan die werkwoord wat 'om te hardloop' beteken, waaruit die begrip wiel afgelei is. Volgens Tasker (1977:76) draai 'n wiel of sirkel om 'n as. Hiervolgens draai 'n mens se lewe vanaf geboorte soos 'n wiel om 'n as. Die invloed van die tong reik dus vanaf die as van die wiel van die lewe tot aan die buitenste rand daarvan. Die tong steek sodoende ' $n$ mens se lewenswiel of lewensloop aan die brand (Pretorius 1988:76).

Die teregwysing in Jakobus 3:10 klink byna soos'n eufemisme: 'My broers, so moet dit nie wees nie.' Die krag van die oproep lê volgens Pretorius (1988:79) juis in die sagtheid en pastorale bewoënheid van die appél opgesluit. Nadat die oorsprong van die vuur, naamlik die hel, aangedui is, word die hoorders nie verdoem nie, maar opgeroep tot die feit dat dit nie so mag wees nie. Volgens Pretorius (1988:79) doen Jakobus dit nie so uit vrees vir die krag van vermaning nie. Hy volg die woorde 'dit hoort nie so nie' op met selfverklarende beelde uit die natuur, naamlik 'n fontein, 'n vyeboom en 'n druiwestok.
Hierdie beelde word deur die woord $\mu$ ï $\iota$ voorafgegaan wat 'n retoriese sin inlei. Hierdie drie beelde veronderstel deurgaans 'n negatiewe antwoord (Kistemaker 1992:116) en laat sodoende die kommunikatiewe doelwit van Jakobus blyk. Die werklikheid van die teks asook die hoorder binne 'n konteks word sodoende op die voorgrond geplaas. Jakobus hou deurgaans in sy woordgebruik sy hoorders in gedagte (vgl. Lange (1987) se woorde: 'Mein Thema ist mein Hörer').

\section{Basisteoretiese afleidings uit Jakobus 3:1-12}

Die volgende afleidings kan gemaak word:

- Jakobus maak seker dat sy lesers sy boodskap verstaan deur eenvoudige en selfverklarende beelde te gebruik.

- Die woordgebruik (styl) van Jakobus getuig daarvan dat sy woorde die boodskap wat hy wil oordra, dien. Verkeerde woorde maak dit immers moeilik vir hoorders om die prediker te volg.

- Die prediker moet waak teen die wyse waarop hoorders vermaan word. Sonder om die erns van vermaning te onderskat, moet vermaning tydens die prediking nie die prediker en hoorders van mekaar vervreem nie.

- Voornaamwoorde moet sinvol aangepas word by die styl van die prediking, sodat die gebruik daarvan reg en toepaslik is.

- Prediking is dialogies van aard. Predikers moet daarop konsentreer om verstaanbare kommunikatiewe taal te gebruik.

\section{Praktykteoretiese perspektiewe op die styl van prediking}

Vanuit die hermeneutiese wisselwerking tussen die bestaande praksis en die basisteoretiese perspektiewe, word die volgende praktykteoretiese perspektiewe gebied. In die wisselwerking waarna verwys is, het dit aan die lig gekom dat die aanwending van styl inderdaad belangrik is in kommunikasie.

\section{Goeie styl vul die ruimte van kommunikatiewe prediking}

Pieterse (2007:122-124) het heeltemal tereg aangetoon dat die prediker met twee kontekste te make het, naamlik die konteks van die teks en die konteks van die hede. Daarom moet predikers moeite doen om die konteks waarin hulle en hulle hoorders leef, grondig te begryp. Die funksionering van die twee kontekste het vanuit die wisselwerking tussen die basisteorie en metateorie na vore gekom. In die dinamika van begrip vir die twee kontekste moet die prediker volgens Pieterse (2007:123) met begrip heen en weer beweeg. Hierdie begrypende aktiwiteit moet 'n konfrontasie met die teks voortbring.

Bogenoemde outeur het in sy besinning daarop gewys dat prediking die ruimte van kommunikasie moet vul. In resente navorsing verwys Cilliers (2008a:8-9) na drie begrippe in sy besinning oor ruimtelikheid, naamlik inruiming, verruiming en ontruiming. Hieronder word verstaan dat die ruimte wat deur die prediking geskep word, verruim moet word 
sodat hoorders met nuwe oë na die werklikheid kan kyk, sodat ontruiming kan plaasvind wat meebring dat die werklikheid van God se Woord tot verandering aanleiding kan gee (Cilliers 2008b:9). In die vul van hierdie ruimte speel die taalgebruik (styl) van predikers 'n vername rol. Woordgebruik in die prediking geskied op planmatige en doelbewuste wyse, aangesien prediking ten doel het om verandering te bewerkstellig. Verstaanbare prediking skep sodoende die ruimte vir hoorders om verder te besin oor die toepassing van die preek binne hulle eie konteks.

\section{Goeie styl beïnvloed die vormgewing van die prediking}

In die vormgewing van preke moet predikers moeite doen om die funksie van taal te begryp. In hierdie opsig moet hulle hulle verdiep in die basiese beginsels van die retorika asook die gebalanseerde wyses waarop die prediking aangebied kan word, naamlik induktiewe (van hoorder na situasie) en deduktiewe (vanaf tema na inhoud) prediking. Die indikatief en imperatief in die prediking moet organies geskied, naamlik vanuit die indikatief van God se genade in Christus na die imperatief. Verder is die gebruikmaking van metafore in die prediking ' $n$ kragtige instrument. Die effek van metafore word egter volgens Venter (2005:235) gemeet aan die funksionaliteit hiervan. Die voorwaarde is dat metafore eietyds moet wees en dat gewone en eenvoudige taal gebruik moet word. Vanuit die Jakobusbrief het dit geblyk dat die aanwending van vars en kreatiewe metafore hoorders help om by nuwe insigte en begrippe uit te kom. 'n Goeie metafoor neem nooit die fokus van die teks af weg nie. Aan die hand van onder meer die metafoor moet die boodskap van die teks glashelder vir die hoorders gemaak word.

Predikers moet moeite doen om nie enige woord as geskik te beskou in die prediking nie. Prediking het immers ten doel om helder en duidelik te kommunikeer. Die wyse waarop taal in die prediking gebruik word, mag nie platvloers en van swak gehalte wees nie, net so min as wat dit aangewend moet word om mense te beïndruk. Daarom is die toets vir eenvoudige prediking die verstaanbaarheid daarvan vir die hoorders.

Verstaanbare prediking is nie net ' $n$ blote ideaal nie, maar 'n opdrag. Prediking moet so verstaanbaar wees soos die voorskrif aan die buitekant van 'n medisynehouer. In die vloei van die woorde in die geskrewe preek, asook die preek wat gelewer word, moet die prediker die hoorders in gedagte hou. In die vormgewing van die preek is die toets deurgaans of die hoorders die vloei van gedagtes en logika sal volg. Die woorde wat die boodskap oordra, moet sorgvuldig gekies word. Predikers moet hulle inspan om eerder korter en meer verstaanbare sinne te gebruik. Korter sinne voorkom dat predikers verdwaal in hulle eie gedagtegang. Eenvoudige en duidelike woorde bevorder goeie styl in die prediking. Die lewering van die preek is die verkeerde geleentheid om hoorders met teologiese woordeskat te beïndruk. In dieselfde asem moet gewaarsku word teen die gebruik van allerlei clichés.
Clichés hou volgens Cilliers (2008a:27) die volgende gevare in:

- In 'n poging om effek te bewerkstellig, ontaard die prediking in ' $n$ eindelose herhaling wat betekenisloos is.

- Clichés maak dit moeilik om kreatiewe beelde en voorbeelde te vind.

- Clichés word gekenmerk deur verkleiningswoorde en oordrywing waardeur die werklikheid van die huidige konteks ontken word.

- Clichés oorvereenvoudig die erns van die lewe. Prediking ontaard sodoende in resepte wat uitgedeel word in plaas daarvan om die Woord in die werklikheid te laat weerklink.

- Clichés openbaar die kringe waarin predikers beweeg, byvoorbeeld hulle kollegas, en die gebruike van die tyd waarin hulle leef. Clichés wil dikwels sensasie skep, maar sodoende kom die helderheid van die preek in gedrang.

\section{Goeie styl kleur die woordkuns van prediking}

Daar is reeds aangetoon dat prediking woorde gebruik amper soos kunstenaars verskillende kleure in hulle kunswerke gebruik. Daarom is prediking woordkuns. Woordgebruik in die prediking moet altyd in diens van die evangelie staan. Woordgebruik in die prediking moet dit vir hoorders nie moeilik maak om vertolkend deel te neem aan die prediking nie. Taalgebruik wat op kunstige wyse aangewend word, skep 'n ruimte vir hoorders om verder na te dink oor die preek en die implikasie daarvan vir hulle lewe. Volgens Stott (1982:229) moet die prediker, nadat hy of sy die dominante gedagte (tema) vasgepen het, moeite doen om slegs die materiaal te gebruik wat daardie dominante gedagte dien.

Selfs in 'n visuele wêreld hou hoorders daarvan dat daar struktuur in die prediking moet wees. Bogenoemde outeur waarsku egter dat die struktuur nie die boodskap moet oorheers nie. Verder moet die struktuur nooit kunsmatig wees nie. Verskillende tekste vereis verskillende strukture en verskillende vormgewing aan preke. Die styl in die prediking het duidelike raakvlakke met die struktuur van die preek. Struktuur in die prediking versterk die inhoud, is in staat om 'n lading te dra en dra daartoe by dat afstande in kommunikasie oorbrug kan word. Goeie struktuur in 'n preek, waaronder goeie styl, bied sodoende aan die inhoud van die prediking 'n woning. Enige struktuur moet egter stewig en stabiel wees om in hierdie behoefte te kan voldoen. 'n Goeie woordkeuse kan funksioneel wees in die skep van 'n stabiele preekstruktuur. Preke sonder stabiliteit het die neiging om uitmekaar te val.

Verder moet predikers rekening hou daarmee dat die stabiele struktuur van 'n preek vergesel moet word van 'n direkte en persoonlike styl in preeklewering. Indien prediking klink soos 'n toespraak wat gememoriseer is en opgesê word, of voorgelees word, ontstaan kommunikasiestoornisse. Hoorders moet onder die indruk verkeer dat daar nie oor hulle nie, maar met hulle gepraat word (Robinson 2001:192). Hierdie persoonlike styl bring mee dat hoorders deeglik kan oordink wat gesê is, terwyl die struktuur van 
die preek dit verder vir hulle vergemaklik. Die woordkuns van die prediking kom daarop neer dat die gedagtes van die prediking met die regte, kleurvolle kleed vergesel moet word (Stott 1982:231).

Wanneer ' $n$ kunswerk bewonder word, roep dit ' $n$ bepaalde herinnering of emosie op. Preke moet in dié sin van die woord lewend wees deurdat dit bepaalde beelde in die hoorder oproep. Die verbeelding en gedagtes van die hoorders moet aan die gang gesit word. Stott (1982:235) waarsku heeltemal tereg teen die gevaar van verbicide oftewel woord-moord. Dit kom daarop neer dat iets gesê word, maar iets heeltemal anders bedoel word. Daarom moet woorde gekies word wat uitdrukking gee aan dit wat die prediker werklik bedoel. Die hoorders moet die beeld van hulle lewens sodoende kan plaas teen die agtergrond van die beeld van God se Woord. Preekstyl kom daarop neer dat die geskikste woorde op die regte plekke gebruik word. Verstaanbare prediking is eenvoudige prediking wat hoorders wil laat nadink.

\section{Eenvoudige en verstaanbare prediking veronderstel verhouding}

Kruger (2002:227) het aangetoon dat die persoon, die integriteit, gesindheid en geloofwaardigheid van die prediker 'n vername rol speel in die kommunikasie-gebeure van die prediking. Bogenoemde sake kan as hulpmiddels maar ook as hindernisse dien in die bemiddelende taak van die prediker, naamlik om hoorders in gesprek met God te bring. Indien die prediker eers self deur die Woord getref is, en hy of sy vir hom- of haarself preek, sny God se Woord deur hom of haar tot die hoorders. Prediking onthul immers altyd ' $n$ magdom dinge, in die besonder die gesindheid van die prediker.

Predikers se styl openbaar baie van hulle persoon en gesindheid. Woordgebruik (styl) vertel derhalwe meer van predikers as wat hulle vermoed. Vanuit die basisteoretiese perspektiewe het die aanspreekvorm my broeders telkens na vore getree. Selfs in die paranese het Jakobus hom op gelyke voet met die hoorders geplaas en op pastorale wyse die skerpte van die Woord op sagte wyse laat weerklink. Daar is ook aangetoon dat predikers hoorders nie uit die hoogte moet aanspreek nie. Die styl van die prediker moet ook in die lewering van die preek direk en persoonlik wees; die styl van iemand wat begryp en saam met die gemeente onderweg is. Die prediker is inderdaad 'n persoon van verhouding, ook met sy of haar hoorders. Hierdie verhouding met die hoorders veronderstel dat die hoflikheidsbeginsel soos die retorika dit onderskei, nagekom moet word. Dit benadruk die feit dat respek vir die prediking en hoorders meebring dat taalgebruik keurig van aard, maar tog ook verstaanbaar moet wees.

\section{Slot}

Hierdie artikel het dit ten doel gehad om aan te toon dat predikers deur middel van woorde in 'n verhouding met hulle hoorders tree. Woorde word in die prediking gebruik om bedoelings en gedagtes mee uit te druk. Die verstaanbaarheid en toepaslikheid van woordgebruik bring kommunikasie voort en veronderstel dat hoorders op 'n bepaalde manier daarop moet kan reageer. Die woorde in 'n preek moet daarom sorgvuldig gekies en gebruik word sodat dit verstaanbaar sal wees en nuwe perspektiewe by hoorders tuisbring. 'n Goeie en opbouende preekstyl behels die gebruik van die mees geskikte woord op die regte plek. Geen preek is voltooi alvorens die mees geskikte woorde gevind en aangewend is nie.

\section{Erkenning Mededingende belange}

Die outeur verklaar dat hy geen finansiële of persoonlike verbintenis het met enige party wat hom nadelig kon beïnvloed in die skryf van hierdie artikel.

\section{Literatuurverwysings}

Adams, J.E., 1982, Preaching with purpose, Zondervan, Grand Rapids.

Arnason, H.H., 1996, A history of modern art, Thames and Hudson, Londen.

Bingle, P.W., 1987, 'God se tolk in die taalvelde van die mens', In die Skriflig 83(21), 2-9.

Burger, C.W., 1995, Gemeentes in transito, Vernuwingsgeleenthede in 'n oorgangstyd, Lux Verbi, Kaapstad.

Capps, C., 1981, Die skeppende mag van woorde, Verenigde Gereformeerde Uitgewers, Brakpan.

Cilliers, J.H., 1996, Die uitwissing van God op die kansel, Ontstellende bevindinge oor Suid-Afrikaanse prediking, Lux Verbi, Kaapstad.

Cilliers, J.H., 1998, Die uitwysing van God op die kansel, Inspirerende perspektiewe op die prediking - om God te sien en ander te laat sien, Lux Verbi, Kaapstad.

Cilliers, J.H., 2000, Die genade van gehoorsaamheid, Hoe evangelies is die etiese preke wat ons in Suid-Afrika hoor?, Lux Verbi, Kaapstad.

Cilliers, J.H., 2003, 'Meer as wat die oog kan sien', Praktiese Teologie In Suid-Afrika $18(1), 8-42$.

Cilliers, J.H., 2007, 'Preaching as language of hope in a context of HIV and AIDS', in C. Vos, L.L. Hogan \& J.H. Cilliers (eds.), Preaching as a language of hope, pp. 155-176, Protea Bookhouse, Pretoria.

Cilliers, J.H., 2008a, 'Silence is golden: Liturgy beyond the edge of language', Praktiese Teologie in Suid-Afrika 23(1), 19-35.

Cilliers, J.H., 2008b, 'In die omtrek van die Gees: 'n Besinning oor die ruimtelikheid van liturgie', Praktiese Teologie In Suid-Afrika 23(2), 1-21.

Coetzee, J.C., 1988, 'Gedagtestruktuurontleding en die eksegese van die Heilige Skrifte', in J.C. Coetzee (red.), Koninkryk, Gees en Woord, bl. 19-36, NG Kerkboekhandel, Pretoria.

Craddock, F.B., 1985, Preaching, Abingdon Press, Nashville, TN.

De Klerk, B.J., 2007, 'Preaching hope within a societal context of hunger and affluence', in C. Vos, L.L. Hogan \& J.H. Cilliers (eds.), Preaching as a language of hope, pp. 177-202, Protea Bookhouse, Pretoria.

Den Dulk, M., 1995, 'De homiletiek van C.J.A. Vos', Praktiese Teologie In Suid-Afrika 10(1), 6-14.

Dingemans, G.D.J., 1991, Als hoorder onder de hoorders, Kok, Kampen.

Dingemans, G.D.J., 1996, Manieren van doen: Inleiding tot de studie van de Practische Theologie, Kok, Kampen.

Douglas, J.D., 1986, 'James', in New Bible Dictionary, p. 550, Callenbach, Wheaton.

Firet, J., 1978, Het agogisch moment in het pastorale optreden, Kok, Kampen.

Flemming, W., 1996, Arts and ideas, Dryden Press, PA.

Gundry, G.H., 1970, A Survey of the New Testament, Zondervan, Grand Rapids.

Habermas, J., 1992, Texte und Kontexte, Heinemann, Londen \& Frankfurt am Main.

Hermelink, J., 2007, 'The theological understanding of preaching hope', in C. Vos, L.L. Hogan \& J.H. Cilliers (reds.), Preaching as a language of hope, pp. 29-58, Protea Bookhouse, Pretoria.

Honour, H. \& Flemming, J., 2002, A world history of art, Laurence King Publishers, London. PMCid:339393

Huebsch, J.C., 1995, Communication skills, Kagiso, Pretoria. PMid:7788881

Immink, F.G., 2003, In God geloven: Een praktisch-theologiese reconstructie, Meinema, Zoetermeer. PMCid:152338

Keulartz, J., 1992, De verkeerde wêreld van Jürgen Habermas, Ton Bolland, Amsterdam. Kimball, D., 2004, Emerging worship, Zondervan, Grand Rapids. 
Kistemaker, S.J., 1992, 'James and I-III John', in New Testament Commentary, Baker House, Grand Rapids. PMCid:1059612

Kruger, F.P., 2002, 'Prediking en gesindheidsverandering, 'n Prakties-teologiese studie in die lig van Hebreërs', ThD-proefskrif, PU vir CHO, Potchefstroom.

Kruger, F.P. \& Venter, C.J.H., 2006, 'Die prediking van geloofsverantwoordelikheid: Homiletiese perspektiewe vanuit Hebreërs', Praktiese Teologie in Suid-Afrika 21(2), 54-71.

Lange, E., 1987, Predigt als Beruf, Aufsätze zu Homiletik, Liturgie und Pfarramt, Chr. Kaiser, München.

Leech, G., 1989, The principles of pragmatics, SCM, Londen.

Lombard, A., 2007, Sensoriese intelligensie, Metz, Welgemoed.

Louw, J.P. \& Nida, E.A., 1993, Greek English Lexicon of the New Testament (I), United Bible Studies, NY.

Martin, R.P., 1988, 'Word Biblical Commentary, vol 48: James' in D.A. Hubbard, G.W. Barker, J.D.W. Watts \& R.P. Martin (eds.), Word Biblical Commentary, pp. 1-222, Protea Bookhouse, Pretoria.

Nel, M., 2003, 'Youth Ministry, The challenge of individuation', Praktiese Teologie in Suid-Afrika 18(1), 151-196.

Nida, E.A., Louw, J.P., Snyman, A.H. \& Cronje, J., 1983, Style and discourse, N.B.P., Goodwood. PMid:6309743, PMCid:217811

Odendal, F.F. (red.), 1995, Verklarende woordeboek van die Afrikaanse taal, Perskor, Johannesburg.

Pieterse, H.J.C., 1985, Verwoording en prediking, NG Kerkboekhandel, Pretoria.

Pieterse, H.J.C., 1987, Communicative preaching, Penrose, Pretoria.

Pieterse, H.J.C., 2001, Prediking in 'n konteks van armoede, ABC, Pretoria. PMCid:64867

Pieterse, H.J.C., 2005, 'Hoe kom God aan die woord in die prediking? Die probleemstelling', Praktiese Teologie in Suid-Afrika 20(1), 77-95.
Pieterse, H.J.C., 2007, 'Hoe kom God aan die woord in die prediking? Die werklikheid van die taal waarin ons oor God praat', Praktiese Teologie in Suid-Afrika 22(1), 118-134.

Pretorius, E.A.C., 1988, Die brief van Jakobus, NG Kerk Uitgewers, Pretoria.

Reierson, G.B., 1988, The art in preaching: The intersection of theology, worship and preaching with the arts, University Press of America, NY. PMid:3351080

Robinson, H.W., 2001, Expository preaching, Principles and practice, Baker House, Gand Rapids.

Smith, J., 2007, "n Gebrek aan jong profete jaag kerklike storms op' in S. Joubert, J. van der Watt, I. Sweet, B. Easum \& N. Niemandt (reds.), Die perfekte storm, bl. 129-144, Christelike Uitgewersmaatskappy, Vereeniging.

Stott, R.W., 1982, I believe in preaching, Hodder \& Stoughton, Londen.

Sweet, L., 2007, 'Sal die kerk van die toekoms vandag oorleef?' in S. Joubert, J. van der Watt, I. Sweet, B. Easum \& N. Niemandt (reds.), Die perfekte storm, bl. 15-44, Christelike Uitgewersmaatskappy (CUM), Vereeniging.

Tasker, R.V.G., 1977, 'The General Epistle of James', in Tyndale New Testament Commentaries, Eerdmans, Grand Rapids.

Traugott, E.C \& Pratt, M.L., 1980, Linguistics, Macmillan, NY.

Venter, C.J.H., 2001, 'Verklarende prediking: 'n Herevaluering', In die Skriflig 35(4), 513-536.

Venter, C.J.H., 2005, 'Prediking wat transformeer - Prakties-teologiese gesigspunte', In die Skriflig 39(2), 217-238.

Vorster, J.M., 1996, Is die kerk nog funksioneel? Gedagtes oor gereformeerde kerkvernuwing in 'n postmoderne konteks, Potchefstroomse Teologiese Publikasies, Potchefstroom.

Vos, C.J.A., 1996, Die volheid daarvan I, Homiletiek uit' $n$ hermeneuties-kommunikatiewe hoek, RGN, Pretoria.

Vos, C.J.A., 2007, 'Preaching the language of hope', in C. Vos, L.L. Hogan \& J.H. Cilliers (eds.), Preaching as a language of hope, pp. 11-28, Protea Bookhouse, Pretoria.

Zerfass, R., 1989, Grundkurs Predigt 1, Spruchpredigt, Chr. Kaiser, München. 